\title{
DESA BINAAN BERBASIS KEARIFAN LOKAL TRI HITA KARANA DI DESA PEMUTERAN KECAMATAN GEROKGAK KABUPATEN BULELENG
}

\author{
oleh, \\ I Wayan Mudana \\ Fakultas Ilmu Sosial \\ Universitas Pendidikan Ganesha
}

\begin{abstract}
ABSTRAK
Pengabdian Kepada masyarakat ini bertujuan untuk (1) meningkatkan wawasan aparat desa dalam berkolaborasi dengan kelompok masyarakat ekonomi, politik dan sipil, (2) meningkatkan pengetahaun dan keterampilan ibu-ibu PKK di Desa Pemuteran dalam mengolah ikan hasil tangkapan, (3) meningkatkan pengetahaun dan keterampilan ibuibu PKK di Desa Pemuteran dalam mengolah ubi ketela pohon dalam membuat beraneka kue kukus, dan (4) meningkatkan wawasan aparat desa, ibu-ibu PKK dan anggota masyarakat tentang pariwisata dan pelestarian lingkungan. Kegiatan ini dilaksanakan dengan metode ceramah, diskusi dan pelatihan. Melalui kegiatan ini dihasilkan peningkatan pengetahuan aparat desa dalam mengembangkan kolaborasi dengan kelompok masyarakat lainnya seperti masyarakat politik, ekonomi dan sipil, peningkatan pengetahuan dan keterampilan aparat desa dan Ibu-Ibu PKK dalam pengembangan pariwisata dan kelestarian lingkungan, peningkatan wawasan dan keterampilan ibu-ibu PKK pembuatan bakso, nugget dan bolu kukus pelangi.
\end{abstract}

Kata-kata kunci: desa binaan, kearifan lokal, desa pemuteran

\begin{abstract}
The social service society aims to (1) improve the knowledge of village officials in collaboration with community groups economic, political and civic, (2) increase knowledge and skills of the PKK in the village of Pemuteran in processing the fish, (3) improve skills and knowledge of PKK group in the village of Pemuteran in processing cassava tubers in making various steamed cake, and (4) improve the knowledge of village officials, the PKK group and members of the public about tourism and environmental preservation. This activity is carried out by the method of lecture, discussion and training. Through these activities produced an increase in knowledge of village officials in developing collaboration with other community groups such as political society, economy and civil, increased knowledge and skills of village officials and PKK group in tourism development and environmental sustainability, increase knowledge and skills PKK manufacture meatballs, nuggets and steamed sponge rainbow.
\end{abstract}

Key words: guided village, local wisdom, pemuteran village 


\section{Pendahuluan}

Desa Pemuteran merupakan salah satu Desa tua yang berada di daerah pesisir Kecamatan Gerokgak Kabupaten Buleleng. Penduduk di Desa Pemuteran berjumlah 9.697 orang, yang terdiri atas 4.753 laki-laki dan 4.944 perempuan dengan jumlah kepala keluarga $2.603 \mathrm{KK}$. Mata pencaharian penduduk sebagian besar sebagai petani termasuk nelayan $(58 \%)$, buruh (6 \%), PNS $(0,86 \%)$, TNI $(0,14 \%)$, Polri $(1,20 \%)$, pegawai swasta $(13,26)$, pedagang $(4,02 \%)$, pertukangan $(2,52 \%)$, belum bekerja $(14$ \%). Di Desa Pemuteran terdapat 2 kelompok nelayan, 5 kelompok peternakan, 1 kelompok wisata bahari, 1 LSM karang Lestari, dan 1 Yayasan Anak Pemuteran.

Dalam sepuluh terakhir, Desa Pemuteran di samping sebagai desa pertanian, dan nelayan juga terus berkembang menjadi desa wisata, hal ini dilihat dari semakin berkembangnya pasilitas kepariwisataan. Pengembangan kepariwisataan, di Desa ini tentu akan berdampak terhadap kehidupan sosial dan kelestarian lingkungan. Sehubungan dengan hal itu perlu diupayakan pengembangan wawasan pelestarian lingkungan dan keperiwisataan. Sehingga pengembangan usaha produktif masyarakat selalu memperhatikan keseimbangan lingkungan sehingga terbina keharmonisan hubungan manusia dengan tuhan dan manusia dengan lingkungan. Menjaga keharmonisan hubungan ini sebagai salah satu aplikasi dari konsep Tri Hita Karana yang merupakan kearifan lokal Bali yang perlu terus dipelihara dan lestarikan. Di samping itu dengan keberadaan Desa Pemuteran yang sebagian masyarakatnya sebagai nelayan perlu kiranya diupayakan kegiatan pelatihan pengolahan ikan bagi anggota PKK Desa Pemuteran. Pentingnya upaya-upaya tersebut juga terkait dengan hasil observasi dan wawancara dengan aparat desa, dan tokoh masyarakat setempat, yang pada prinsipnya menyatakan perlunya upaya pendalaman penguatan kelembagaan desa, khususnya terkait dengan berkolaborasi dengan berbagai pihak, wawasan kepariwisataan, lingkungan dan pengembangan kuliner berbasis potensi lokal. Berdasarkan uraian di atas, maka pada kegiatan pengabdian masyarakat pada tahun ini akan difokuskan pada penanganan permasalahan pariwisata, lingkungan, penguatan kelembagaan desa, dan pelatihan pengolahan ikan dan ubi ketela pohon. 


\section{Metoda Pelaksanaan Pengabdian}

Khalayak yang dijadikan sasaran pada kegiatan P2M ini adalah aparat desa, masyarakat desa, khususnya Ibu-ibu PKK di Desa Pemuteran . Masalah pokok yang akan dipecahkan dalam P2M ini berkaitan dengan kekurang pahaman aparat desa terhadap pentingnya kolaborasi dengan masyarakat ekonomi, politik, dan sipil, kekurang pahaman terhadap pengembangan kepariwisataan dan pelestarian lingkungan. Demikian juga dengan ibu-ibu PKK di Desa Pemuteran yang kurang memiliki pengetahuan dan keterampilan dalam membuat bakso, nugget, dan bolu kukus pelang, serta kekurang pahaman terhadap pengembangan kepariwisataan dan pelestarian lingkungan. Berbagai alternatif untuk memecahkan permasalahan tersebut disajikan pada Tabel 1.

Tabel 1. Alternatif Pemecahan Masalah

\begin{tabular}{|c|c|c|c|}
\hline No. & Permasalahan & Akar Masalah & $\begin{array}{c}\text { Aternatif Pemecahan } \\
\text { Masalah }\end{array}$ \\
\hline 1. & $\begin{array}{l}\text { Aparat Desa kurang } \\
\text { memahami } \\
\text { pentingnya Pemuteran } \\
\text { kurang memahami } \\
\text { berkolaborasi dengan } \\
\text { klp masyarakat eko, } \\
\text { pol, dan sipil, serta } \\
\text { pengembangan } \\
\text { pariwisata dan } \\
\text { pentingnya pelestarian } \\
\text { lingkungan }\end{array}$ & $\begin{array}{l}\text { Kurangnya informasi } \\
\text { dan pengetahuan } \\
\text { tentang berkolaborasi } \\
\text { dengan klp masyarakat } \\
\text { eko, pol, dan sipil, serta } \\
\text { pengembangan } \\
\text { pariwisata dan } \\
\text { pentingnya pelestarian }\end{array}$ & $\begin{array}{ll}\text { 1. } & \text { Penyebaran informasi } \\
\text { 2. } & \text { Pemberian ceramah dan } \\
& \text { diskusi }\end{array}$ \\
\hline 2. & $\begin{array}{l}\text { Ibu-ibu PKK di Desa } \\
\text { Pemuteran kurang } \\
\text { memahami pembuatan } \\
\text { bakso dan nugget }\end{array}$ & $\begin{array}{l}\text { Kurangnya informasi } \\
\text { dan keterampilan } \\
\text { tentang pembuatan } \\
\text { bakso dan nugget }\end{array}$ & $\begin{array}{ll}\text { 1. } & \text { Penyebaran informasi } \\
\text { 2. } & \text { Pemberian ceramah dan } \\
\text { diskusi }\end{array}$ \\
\hline 3. & $\begin{array}{l}\text { Ibu-ibu PKK di Desa } \\
\text { Pemuteran kurang } \\
\text { memahami pembuatan } \\
\text { bolu kukus pelangi } \\
\text { dari ubi ketela pohon }\end{array}$ & $\begin{array}{l}\text { Kurangnya informasi } \\
\text { dan keterampilan } \\
\text { tentang pembuatan bolu } \\
\text { kukus pelangi }\end{array}$ & $\begin{array}{ll}\text { 1. } & \text { Penyebaran informasi } \\
\text { 2. } & \text { Pemberian ceramah dan } \\
\text { diskusi }\end{array}$ \\
\hline
\end{tabular}

Berdasarkan rumusan alternatif pemecahan masalah dalam tabel di atas, solusi yang dipilih untuk memecahkan permasalahan tersebut adalah: pemberian ceramah, diskusi, dan pelatihan. 


\section{Hasil dan Pembahasan}

Kegiatan P2M ini dilaksanakan dalam dua tahap yaitu: 1) dialog dan pelatihan pengembangan wawasan tentang peningkatan wawasan aparat desa pemuteran tentang pentingnya berkolaborasi dengan masyarakat ekonomi, politik dan sipil dalam pembangunan desa, peningkatan wawasan kepariwisataan dan lingkungan, dan 2) dialog dan pelatihan pengembangan wawasan dan keterampilan ibu-ibu PKK desa Pemuteran dalam membuat bakso, nugget, dan bolu pelang, serta wawasan pariwisata dan pelestarian lingkungan.

Kegiatan ini ditujukan kepada aparat desa Pemuteran Kecamatan Gerokgak yang dilaksanakan pada hari Sabtu 23 November 2013 di Bali Desa setempat. Kegiatan ini dihadiri oleh 11 orang aparat desa setempat dari 20 orang yang diundang. Adapun aparat desa yang hadir dalam kegiatan ini disajikan dalam table berikut.

Tabel 4.1 Aparat Desa yang Hadir dalam Kegiatan Dialog dan Pelatihan

\begin{tabular}{|c|l|l|}
\hline No & \multicolumn{1}{|c|}{ Nama } & \multicolumn{1}{c|}{ Jabatan } \\
\hline 5. & I Made Sulandra & Sekretaris Desa \\
\hline 6. & I Ketut Mahardika & Kaur Pembangunan \\
\hline 7. & Ni Ketut Ari Setiawati & Kaur Kesra \\
\hline 8. & Ni Luh Sumartini & Kaur Umum \\
\hline 9. & I Wayan Suarta & Kaur Pemerintahan \\
\hline 6. & M.Zainal.A & Kaur Keuangan \\
\hline 7 & I Wayan Ladra & Staf Desa \\
\hline 8. & I Kadek Wenten & Staf Desa \\
\hline 9. & Made Gunaksa & Pecalang Segara \\
\hline 10. & Ketut Ari Setiawati & PKK \\
\hline 11. & Nurhaeti & PKK \\
\hline
\end{tabular}

Kegitana ini berlangsung sangat interaktif dan lancar. Peserta menunjukkan antusianisme yang cukup tinggi, hal ini dapat dilihat dari perhatian dan adanya beberapa pertanyaan yang diajukan oleh peserta. Pertanyaan peserta meliputi permasalahan yang diadapi dalam kaitannya dengan kondisi kualitas sumber daya manusia dan upaya untuk peningkatannya, permasalahan yang terkait dengan mekanisme pengembangan kolaborasi, upaya kelembagaan yang bersiofat sistemik dan terstruktur dalam berkolaborasi, upaya-upaya terstruktur dalam mempertahankan kepercayaan dan kesadaran masyarakat dalam mendukung program pembangunan pariwisata dan 
pelestarian lingkungan. Berpijak dari pertanyaan dan tanggapan-tanggapan yang disampiakan diindikasikan peserta pelatihan ini telah mengalami peningkatan wawasan dalam kaitannya dengan pentingnya berkolaborasi, pengembangan pariwisata dan pelestarian lingkungan.

Dari wawancara yang dilakukan terhadap beberapa orang peserta kegiatan ini dapat diungkapkan bahwa responnya sangat positif, bahkan tokoh aparat desa mengharapkan agar kegitan ini terus dilajutkan pada tahun-tahun berikutnya. Kegiatan ini dilaksanakan pada hari sabtu, 30 November 2013 di balai Desa Pemuteran. Peserta yang hadir dalam kegiatan ini sebanyak 21 orang dari 20 orang yang diundang. Ibu-ibu PKK yang hadir dalam kegiatan ini sebagaimana terlihat dalam tabel 4.3 berikut:

Tabel 4.3 Ibu-ibu PKK yang Hadil dalam Dialog dan Pelatihan

\begin{tabular}{|l|l|l|l|}
\hline No. & \multicolumn{1}{|c|}{ Nama } & No. & \multicolumn{1}{|c|}{ Nama } \\
\hline 1. & Km Mahayoni & 12. & Kd. Ariani \\
\hline 2. & Kd Dresti & 13. & Ni Luh Putu Indrayani \\
\hline 3. & Putu Artini & 14. & Kt. Sudarmi \\
\hline 4. & Ni Made Narwi & 15. & I Gst Kt Sutarini \\
\hline 5. & Ni Luh Ayu & 16 & Luh Budiasmini \\
\hline 6. & Km Ayu Armini & 17. & Ni Kd Yoni Asih \\
\hline 7. & Kt Yeni & 18. & Km Yuni Asih Febriana \\
\hline 8. & Luh Swastini & 19. & Nurhaeti \\
\hline 9. & Luh Sumartini & 20. & Ni Km Eliantini \\
\hline 10. & Km Yuni & 21. & Ni Kt Arisetiawati \\
\hline 11. & Km Darmini & 22. & I Ketut Mahardika \\
\hline
\end{tabular}

Ibu-ibu PKK di Desa Pemuteran merasa sangat senang mendapatkan ceramah dan pelatihan tentang pariwisata, pelestarian lingkungan dan pembuatan Bakso, Nugget, dan Bolu Kukus Pelangi. Karena kegiatan ini tidak saja memeperluas luas wawasannya tentang kepariwisataan, pelestarian lingkungan, tetapi juga telah mengembangkan keterampilannya dalam memanfaatkan berbagai potensi lokal untuk pemertahanan pangan dalam bentuk olahan yang sangat bervariasi. Di samping itu kegiatan ini juga memebrikan keberikan kontribusi bagi peningkatan kehidupan ekonomi keluarga, paling tidak mengurangi beban ekonomi keluarga. Karena produk dari kegiatan ini seperti bakso, nugget, dan bolu kukus pelangi, merupakan makanan-makanan yang sangat disukai oleh anggota keluarga terutama bagi anak-anak dan remaja. Di samping itu keterampilan yang diperoleh juga akan dapat dikontribusikan secara tidak langsung 
untuk meningkatkan gizi dan kesehatan keluarga. Karena produk yang dihasilakan terbuat dari bahan-bahan dan alat-alat yang memenuhi standar gizi dan kesehatan. Keunggulan lainnya dari produk ini adalah bahan yang digunakan sesuai dengan potensi lokal baik yang berasal dari lingkungan pesisir ( ikan) maupun yang berasal dari hasil perkebunan setempat ( ketela pohon).

\section{Penutup}

Berdasarkan atas hasil dan pembahasan di atas maka dapat disimpulkan sebagai berikut: (1) Kegiatan P2M desa binaan dapat meningkatkan pengetahuan aparat desa dalam mengembangkan kolaborasi dengan kelompok masyarakat lainnya seperti masyarakat politik, ekonomi dan sipil, (2) Kegiatan P2M desa binaan dapat meningkatkan pengetahuan dan keterampilan aparat desa dan Ibu-Ibu PKK dalam pengembangan pariwisata dan kelestarian lingkungan, dan (3) Kegiatan P2M desa binaan dapat meningkatkan wawasan dan keterampilan ibu-ibu PKK pembuatan bakso, nugget dan bolu kukus pelangi.

\section{DAFTAR PUSTAKA}

Althuser, Louis. 2006. Tentang Ideologi, Marxisme,strukturalis, Psikoanalisis, Cultural Studiies. Yogyakarta: Jalasutra.

Anom,I Putu.2010. Pembangunan Kepariwisataan Berkelanjutan, dalam dalam Pariwisata Berkelanjutan dalam Pusaran Krisis Global (Penyunting, I Putu Anom, dkk).

Ardika, I Wayan, 2011. Gastronomi dalam Pariwisata Budaya, dalam Pemberdayaan dan Hiperdemokrasi dalam Pembangunan Pariwisata. (Penyunting I Nyoman Darma Putra dan I Gde Pitana), Denpasar: Pustaka Larasan.

Bocok, Robert. 2007. Pengenatar Komprehensif Untuk Memahami Hegemoni. Yogyakarta: Jalasutra.

Budiman, Arief,1996, Teori Pembangunan Dunia Ketiga, Jakarta: Gramedia.

Covarrubias,Miguel. 2013. Pulau Bali Temuan Yang Menakjubkan. Denpasar: Universitas Udayana.

Effendy,Muhadjir. 2002. Masyarakat Equilibrium. Yogyakarta: Bentang Budaya.

Fakih,Mansour,2003,Runtuhnya Teori Pembangunan dan Globalisasi,Yogyakarta: Imssit Press 
Gidden, Anthony, 2002, Masyarakat Post-Tradisional (Penterjemah: Ali Noer Zaman), Yogyakarta: IRCiSod.

Korten, David C., 1993, Menuju Abad Ke 21: Tindakan Sukarela dan Agenda Global, Jakarta: Sinar Harapan.

Kusnadi, 2003. Akar Kemiskinan Nelayan. Yogyakarta: LkiS.

Mudana, I Wayan,2012..Kuasi Kolaborasi Masyarakat Ekonomi, Politik dan Sipil dalam Menginvestasikan Modal Sosial Untuk Kelestaraian Lingkungan Laut dan Pesisir di Desa pemuteran,Gerokgak, Buleleng, Bali, (Desertasi). Denpasar: Universitas Udayana.

Sanderson, Stephen K., 1993, Sosiologi Makro, Jakarta: Rajawali.

Setiawan, Bonnie. 1996. "Masyarakat Sipil dan Organisasi NonPemerintah" dalam Prisma. No.7/1996. Jakarta: LP3ES.

Sugiono,Muhadi. 1999. Kritik Antonio Gramsci Terhadap pembangunan Dunia Ketiga. Yogyakarta: Pustaka Pelajar.

Suwena, I Ketut. 2010, Format Pariwisata Masa Depan, dalam Pariwisata Berkelanjutan dalam Pusaran Krisis Global (Penyunting, I Putu Anom, dkk).

Turner,Bryan S. 2006. Runtuhnya Universalisme Sosiologi Barat. Jogjakarta: Ar-Ruzz

. Vickers, Adrian. 2012. Bali Tempo Doeloe. Jakarta: Komunitas Bambu 